\title{
Correlation Between 25-Hydroxyvitamin D and Estradiol Serum Level in Determining Bone Density in Menopausal Women
}

\author{
Muhammad Rusda \\ Department of Obstetrics and Gynecology, Faculty of Medicine University of Sumatera Utara, Indonesia \\ rahmipramulia86@gmail.com
}

\begin{abstract}
Postmenopausal osteoporosis is one of the world's concern with high morbidity and mortality which is marked by low bone density which makes the bone fragile and increases the risk of fracture. It had be known that estrogen plays a role in women's bone health, that is to maintain the activity of osteoblasts and osteoclasts. Vitamin D which is reflected by 25 Hydroxyvitamin D (25(OH)D) serum is also known to be important to stimulate the absorbtion of calcium in the small intestine for bone mineralization and in the state of vitamin $D$ deficiency, it increases bone turnover by causing secondary hyperparathyroidism. To know the correlation between $25(\mathrm{OH}) \mathrm{D}$ and estradiole serum level with bone densities in menopausal women.This is an analytic research with cross sectional approach performed on 36 menopaused midwives/nurses in RSUP. $H$. Adam Malik Medan, from September-October 2015. We measure the level of $25(\mathrm{OH}) \mathrm{D}$ and estradiole serum, bone density were measured using Dual energy X-ray Absorbtiometry (DXA) method, and then were analized with multiple correlation test. From the characteristics, it is found that most of them is aged > $50(80,6 \%)$, menopause since $3-4$ years ago $(55,6 \%)$, normoweight BMI $(47,2 \%), 25(\mathrm{OH}) \mathrm{D}$ level $\leq 20 \mathrm{ng} / \mathrm{ml}(69,4 \%)$, estradiole level $\leq 20 \mathrm{pg} / \mathrm{ml}(88,9 \%)$, and osteopenia $(63,9 \%)$. Based on chi-square, from the risk factors, only Body Mass Index shows a significant correlation with bone densitiy and estradiole rate $(p=0,015$ and $p=0,005)$. According to Spearman correlation test, there is no significant corelations between $25(\mathrm{OH}) \mathrm{D}$ serum level and $T$-score $(r=0,261, p>0,05)$. There is a significant positive corelations between estradiole serum and $T$-score $(r=0,53$, $\mathbf{p}<0,05)$ and with multiple corelation test, there is a significant positive corelations between $25(\mathrm{OH}) \mathrm{D}$ rate and estradiole serum with $T$-score $(R=0,0663$ and $p<0,05)$. Level of $25(\mathrm{OH}) \mathrm{D}$ and Estradiole serum have a contribution value as much as $44 \%$ towards bone density $\left(R^{2}=0,44\right)$. There is a significant positive corelations between the level of $25(\mathrm{OH}) \mathrm{D}$ and estradiole serum towards bone density score (T-score).
\end{abstract}

Keywords - 25 Hydroxyvitamin D, estradiole, osteoporosis, Tscore, bone mineral density, menopause.

\section{INTRODUCTION}

One of the impacts of improved health development in Indonesia is the increasing life expectancy of 64-71 years old (1995-2000) to 67-68 years old (2000-2005). This makes Indonesia became the fourth country in the world after China, India, and the United States with the elderly population. Thus, there will be an increase in the problem of degeneration such as in menopause is osteoporosis [1].

The pathogenesis of postmenopausal osteoporosis involves many factors such as estrogen deficiency, low calcium intake, vitamin $\mathrm{D}$ deficiency and secondary hyperparathyroidism. Serum estradiol levels were decreased to a loss of markers of ovarian function in postmenopausal women. It is known that estrogen plays an important role in determining bone health in women, ie in maintaining a balance of work osteoblast (bone formation) and osteoclasts (bone resorption).

Hipoestrogen circumstances in postmenopausal women at increased risk of osteoporosis with an increased osteoclast formation and increased bone turnover [2], [3], [4].

The majority of studies indicate no association between serum estradiol level with Bone Mineral Density (BMD). Pham et al. (2013) showed a significant correlation between the levels of estradiol with BMD in both men and women. Hulking et al. (2004) showed estradiol significantly associated with lumbar vertebra, and only a few relationships in the proximal femur and total order. Mawi et al. (2010) showed no relationship between the levels of estradiol with femoral neck BMD but not at the lumbar spine and distal radius. Rogers et al. (2012) showed serum estradiol levels were positively associated with bone mass density absolute in all bodies [5], [6], [7].

The most important role of vitamin $\mathrm{D}$ is to trigger the absorption of calcium in the small intestine to the function of bone mineralization, without the help of vitamin D, only $10-15 \%$ of calcium and $60 \%$ phosphate can be absorbed in the intestine, compared with the aid of vitamin D which increase 
the absorption of calcium to $30-40 \%$ and $80 \%$ phosphate. Vitamin D deficiency, triggers the secretion of parathyroid hormone, which if sustained will increase osteoclast formation which will dissolve the collagen matrix of bone demineralization and occurs so that the calcium ions released into circulation [8], [9], [10].

There is still a controversial relationship between the levels of $25(\mathrm{OH}) \mathrm{D}$ serum and bone density. Some studies show different results of research that indicates there is a relationship between vitamin $D$ levels with bone density while Rassouli et al research and studies did not show an association between vitamin D levels with bone density as well as in the research of Allali Garnero et al and Hosseinpanah et al [5], [6], [7]. Based on the various results of this study, researchers are interested in studying the relationship between the levels of $25(\mathrm{OH}) \mathrm{D}$ as a measure of a store of vitamin $\mathrm{D}$ in the human body and serum estradiol with bone density in postmenopausal women using dual energy X-ray Absorbtiometry (DXA) as the gold standard for osteoporosis examination.

\section{METHOD}

This study was approved by the Ethics Committee of the Faculty of Medicine, University of North Sumatra. All study participants were included in the study, were given an explanation of the purpose, benefits, and risks of research and the responsibilities of researchers. After the participants understood, they were required to give an approval by signing a statement of consent that had been provided. Every patient was entitled to know the results of the inspection and may withdraw from the study if they were not willing to continue the research.

A total of 36 samples consisting of menopausal midwives and nurses in Dr H. Adam Malik were included in the study which was carried out from Septermber 2015 - October 2015.

Inclusion criteria for the study was a midwife and nurse in RSUP. HAM hospital and other hospital who menopausal / no menstrual $\geq 12$ consecutive months and are willing to participate in the study and signed the form of availability. While exclusion criteria are: broken blood serum; withdrawal from the study; suffering from malignant disease, kidney disease, parathyroid disease, liver disease; use of hormone replacement therapy; had a history of surgical removal of the ovaries; and the habit of smoking and drinking alcohol.

The study participants then had their blood drawn as much as $10 \mathrm{cc}$ of median cubital vein participants to measure levels of estradiol and $25(\mathrm{OH}) \mathrm{D}$, which is examined in the laboratory Prodia. After that patients were welcome to follow the procedure BMD measurements by DXA method in RS. Medan Setia Budi.

Levels of vitamin D in this study were defined as levels of $25(\mathrm{OH}) \mathrm{D}$ in the serum were measured using ELISA and then categorized into category 1 $(\geq 20 \mathrm{ng} / \mathrm{ml})$ and $2(<20 \mathrm{ng} / \mathrm{ml})$ and using the measuring scale ratio. Estradiol levels in serum were measured by CLIA and also classified into two categories, namely the category $1(>20 \mathrm{pg} / \mathrm{ml})$ and the category $2(\leq 20 \mathrm{pg} / \mathrm{ml})$ with a measuring scale ratio.

Bone mass density is defined as bone mineral content which is measured at the femoral neck bone by using DXA (Dual energy X-ray Absorbtiometry) and categorized into category 1 (Normal values $\geq$ 1 ), category 2 (Osteopenia with values $<-1 \mathrm{~s} / \mathrm{d}$ 2.5) and category 3 (Osteoporosis with a score of <2.5) with ordinal measuring scale.

Data were collected and analyzed statistically to see the frequency distribution variables studied. Then analyzed to relate the levels of $25(\mathrm{OH}) \mathrm{D}$ serum and serum estradiol on bone density.

\section{RESULT}

Characteristics of research subjects are described in Table 1 and it was found that the age of most research subjects is $>50$ years old $(80.6 \%)$, with long menopause is generally 3-4 years $(55.6 \%)$ with a body mass index normal weight $(47.2 \%)$, levels of $25(\mathrm{OH}) \mathrm{D}$ serum most common with the results of deficiency $(<20 \mathrm{ng} / \mathrm{ml})$, ie $69.4 \%$, estradiol levels are often found $\leq 20 \mathrm{pg} / \mathrm{ml}$ which was $88.9 \%$ while the highest bone density status characteristics found in osteopenia group $(63,9 \%)$.

Based on table 4.1. it can be seen that based on the characteristics of the age of the study most subjects were from the age group $>50$ years as many as 29 people $(80.6 \%)$ with menopause generally 3-4 years old were 20 people $(55.6 \%)$, 
while for the characteristics of body mass index (IMT) are largely normoweight many as 17 people $(47.2 \%)$, the rest overweight and obese, may not find study subjects included underweight group.

TABLE I

CHARACTERISTICS OF RESEARCH SUBJECTS

\begin{tabular}{|c|c|c|}
\hline Characteristics & N & \% \\
\hline Category Age & & \\
\hline$\leq 50$ yo & 7 & 19,4 \\
\hline$>50$ yo & 29 & 80,6 \\
\hline Duration of Menopause & & \\
\hline $1-2$ yo & 6 & 16,7 \\
\hline $3-4$ yo & 20 & 55,5 \\
\hline$\geq 5$ yo & 10 & 27,8 \\
\hline IMT & & \\
\hline Underweight & 0 & 0 \\
\hline Normoweight & 17 & 47,2 \\
\hline Overweight & 10 & 27,8 \\
\hline Obese & 9 & 25.0 \\
\hline Level of $25(\mathrm{OH}) \mathrm{D}$ Serum & & \\
\hline$<20 \mathrm{ng} / \mathrm{ml}$ & 25 & 69,4 \\
\hline$\geq 20 \mathrm{ng} / \mathrm{ml}$ & 11 & 30,6 \\
\hline Level of Estradiol Serum & & \\
\hline$\leq 20 \mathrm{pg} / \mathrm{ml}$ & 32 & 88,9 \\
\hline$>20 \mathrm{pg} / \mathrm{ml}$ & 4 & 11,1 \\
\hline Bone density status & & \\
\hline Normal & 7 & 19,4 \\
\hline Osteopenia & 25 & 69,4 \\
\hline Osteoporosis & 4 & 11,1 \\
\hline
\end{tabular}

For levels of $25(\mathrm{OH})$ D serum most common with the results of deficiency ( $<20 \mathrm{ng} / \mathrm{ml})$ as many as 25 people $(69.4 \%)$ and the rest $\geq 20 \mathrm{ng} / \mathrm{ml}(11 /$
$30.6 \%$ ), while the estradiol levels encountered $\leq$ $20 \mathrm{pg} / \mathrm{ml}$ as many as 32 people $(88.9 \%)$ and only 4 (11.1\%) who had estradiol values above normal values $(>20 \mathrm{pg} / \mathrm{ml})$. Based on the characteristics of the most common bone density status in osteopenia group of 25 people (69.4\%), 7 (19.4\%) in the group of normal bone density and $4(11.1 \%)$ in the group of osteoporosis.

Based on table 4.2. picture obtained the status of bone density by a factor of risk, to categories of age $\leq 50$ years found most osteopenia as many as 6 people $(85.7 \%)$ and only $1(14.3 \%)$ who had normal bone status, without having encountered the subject of osteoporosis , At the age of $>50$ years found most osteopenia as many as 19 people (65.5\%) followed by normal bone density status as 6 people (20.7\%) and osteoporosis as many as four people $(13.8 \%)$.

To the old category menopause, between 1-2 years most have osteopenia 5 people $(83.3 \%)$ and normal bone density by 1 person $(16.7 \%)$ in the absence of the subject of osteoporosis. In the long span of 3-4 years of menopause was found most osteopenia as many as 14 people $(70 \%)$, normal 5 people $(25 \%)$ and osteoporosis $1(5 \%)$. While the menopause $\geq 5$ years old, most still in osteopenia 6 $(60 \%)$, followed by osteoporosis 3 people $(30 \%)$ and normal 1 person $(10 \%)$.

TABLE II

STATUS OVERVIEW BASED RISK FACTORS BONE DENSITY

\begin{tabular}{|c|c|c|c|c|c|c|c|}
\hline \multirow{3}{*}{ Characteristics } & \multicolumn{6}{|c|}{ Bone density } & \multirow{3}{*}{ P value } \\
\hline & \multicolumn{2}{|c|}{ Normal } & \multicolumn{2}{|c|}{ Osteopenia } & \multicolumn{2}{|c|}{ Osteoporosis } & \\
\hline & $\mathbf{n}$ & $\%$ & $\mathbf{n}$ & $\%$ & $\mathbf{n}$ & $\%$ & \\
\hline \multicolumn{8}{|l|}{ Category Age } \\
\hline$\leq 50$ yo & 1 & 14,3 & 6 & $\mathbf{8 5 , 7}$ & 0 & 0 & $0,822 *$ \\
\hline$>50$ yo & 6 & 20,7 & 19 & 65,5 & 4 & 13,8 & \\
\hline \multicolumn{8}{|l|}{ Duration of Menopause } \\
\hline $1-2$ yo & 1 & 16,7 & 5 & $\mathbf{8 3}, 3$ & 0 & 0 & $0,368 *$ \\
\hline $3-4$ yo & 5 & 25 & 14 & 70 & 1 & 5 & \\
\hline$\geq 5$ yo & 1 & 10 & 6 & 60 & 3 & 30 & \\
\hline \multicolumn{8}{|l|}{ IMT } \\
\hline Normoweight & 0 & 0 & 14 & 82,4 & 3 & 17,6 & $0,015 *$ \\
\hline Overweight & 2 & 20 & 7 & 70 & 1 & 10 & \\
\hline Obese & 5 & 55,6 & 4 & 44,4 & 0 & 0 & \\
\hline
\end{tabular}


For the category of body mass index normal weight found most osteopenia as many as 14 people (82.4\%), followed by osteoporosis as many as three people $(17.6 \%)$ with no common status normal bone density. In the overweight group found most osteopenia of 7 people (70\%), followed by normal bone density status $2(20 \%)$ and osteoporosis 1 person $(10 \%)$. In the obese group with the most common status normal bone density by 5 people $(55.6 \%)$ and osteopenia as many as four people (44.4\%), osteoporosis is not found in the obese group.

Statistically with Chi-square test showed no significant difference in bone density based on the characteristics of age, duration of menopause $(p>$
$0.05)$ but showed significant differences between body mass index and bone density $(p=0.015)$.

Based on Table 4.3. picture obtained levels of 25 $(\mathrm{OH}) \mathrm{D}$ serum is based on risk factors, to $\leq 50$ years age category with the most common normal status of 4 people $(57.1 \%)$ and in those aged $>50$ years with the most common deficiency status as many as 22 people $(75,9 \%)$, with mean levels of $25(\mathrm{OH}) \mathrm{D}$ in subjects aged $\leq 50$ years $(21.59 \pm 4.61)$ is greater than the average subject age $>50$ years $(15.52 \pm$ 5.33).

To the old category menopause, between 1-2 years obtained the same number of subjects between normal and deficient status.

TABLE III

OVERVIEW LEVELS OF 25 (OH) D SERUM BASED RISK FACTORS

\begin{tabular}{|c|c|c|c|c|c|c|}
\hline \multirow[t]{3}{*}{ Characteristic } & \multicolumn{4}{|c|}{ 25(OH)D serum level } & \multirow[t]{3}{*}{ P value } & \multirow{3}{*}{$\begin{array}{l}\text { Mean } \pm \text { SD } \\
(\mathrm{ng} / \mathrm{ml})\end{array}$} \\
\hline & \multicolumn{2}{|c|}{$<20 \mathrm{ng} / \mathrm{ml}$} & \multicolumn{2}{|c|}{$\geq 20 \mathrm{ng} / \mathrm{ml}$} & & \\
\hline & $\mathbf{n}$ & $\%$ & $\mathbf{n}$ & $\%$ & & \\
\hline \multicolumn{7}{|l|}{ Category Age } \\
\hline$\leq 50$ yo & 3 & 42,9 & 4 & 57,1 & $0,213 *$ & $21,59 \pm 4,61$ \\
\hline$>50$ yo & 22 & 75,9 & 7 & 24,1 & & $15,52 \pm 5,33$ \\
\hline \multicolumn{7}{|l|}{$\begin{array}{l}\text { Duration of } \\
\text { Menopause }\end{array}$} \\
\hline $1-2$ yo & 3 & 50 & 3 & 50 & $0,541 * *$ & $19,7 \pm 6,26$ \\
\hline $3-4$ yo & 15 & 75 & 5 & 25 & & $16,53 \pm 5,1$ \\
\hline$\geq 5$ yo & 7 & 70 & 3 & 30 & & $15,19 \pm 6,47$ \\
\hline \multicolumn{7}{|l|}{ IMT } \\
\hline Normoweight & 14 & 82,4 & 3 & 17,6 & $1,0^{*}$ & $16,39 \pm 4,01$ \\
\hline Overweight & 5 & 50 & 5 & 50 & & $16,79 \pm 8,58$ \\
\hline Obese & 6 & 66,7 & 3 & 33,3 & & $17,36 \pm 5,01$ \\
\hline
\end{tabular}

In the long span of 3-4 years of menopause was found by as many as 15 people deficiency status $(75 \%)$ and at menopause $\geq 5$ years old were found most also with deficiency status of 7 people $(70 \%)$, but based on the average levels of $25(\mathrm{OH}) \mathrm{D}$ serum, at menopause 1-2 years old group (19.7 \pm 6.26) was higher than the 3-4 years group (16.53 \pm $5.1)$ and $\geq 5$ years group $(15.19 \pm 6.47)$.

For the category of body mass index with the highest encountered normoweight deficiency status as many as 14 people $(82.4 \%)$, in the overweight group found the same number of subjects between normal and deficient status, while the obese group with the most common deficiency status as many as 6 people $(66,7 \%)$. For the mean value of the levels of $25(\mathrm{OH}) \mathrm{D}$ almost same three groups, namely: normoweight $(16.39 \pm 4.01)$, overweight (16.79 \pm $8.58)$ and Obese (17.36 \pm 5.01$)$.

Statistically with Chi-square test showed no significant difference in levels of $25(\mathrm{OH}) \mathrm{D}$ serum is based on the characteristics of age, duration of menopause or BMI ( $p>0.05)$. 
TABLE IV

SERUM ESTRADIOL LEVELS OVERVIEW BASED RISK FACTORS

\begin{tabular}{|c|c|c|c|c|c|}
\hline \multirow[t]{3}{*}{ Characteristic } & \multicolumn{4}{|c|}{ Estradiol serum level } & \multirow[t]{3}{*}{ P value } \\
\hline & \multicolumn{2}{|c|}{$\leq 20 \mathrm{pg} / \mathrm{ml}$} & \multicolumn{2}{|c|}{$>20 \mathrm{pg} / \mathrm{ml}$} & \\
\hline & $\mathbf{N}$ & $\%$ & $\mathbf{N}$ & $\%$ & \\
\hline \multicolumn{6}{|l|}{ Category Age } \\
\hline$\leq 50$ yo & 7 & 100 & 0 & 0 & $0,710^{*}$ \\
\hline$>50$ yo & 25 & 86,2 & 4 & 13,8 & \\
\hline \multicolumn{6}{|c|}{ Duration of Menopause } \\
\hline $1-2$ yo & 5 & 83,3 & 1 & 16,7 & $1,0 * *$ \\
\hline $3-4$ yo & 18 & 90 & 2 & 10 & \\
\hline$\geq 5$ yo & 9 & 90 & 1 & 10 & \\
\hline \multicolumn{6}{|l|}{ IMT } \\
\hline Normoweight & 17 & 100 & 0 & 0 & $0,005 *$ \\
\hline Overweight & 10 & 100 & 0 & 0 & \\
\hline Obese & 5 & 55,6 & 4 & 44,4 & \\
\hline
\end{tabular}

TABLE VI

According to the table 4.4. picture obtained serum estradiol levels based on risk factors, for the category of age $\leq 50$ years found all subjects had higher levels of $\leq 20 \mathrm{pg} / \mathrm{ml}$, at age $>50$ years was found with the highest levels of $\leq 20 \mathrm{pg} / \mathrm{ml}$ as many as 25 people (86.2\%).

For all the old category menopause, most subjects were found with levels of $\leq 20 \mathrm{pg} / \mathrm{ml}$, namely; on a long menopause 1-2 years as many as five people (83.3\%), on a long menopause 3-4 years as many as 18 people $(90 \%)$ and the menopause $\geq 5$ years old were 9 people $(90 \%)$.

TABLE $\mathrm{V}$

THE RESULTS OF CORRELATION TEST LEVELS OF 25 (OH) D SERUM WITH A SCORE OF BONE DENSITY

\begin{tabular}{|c|c|c|}
\hline Research variable & R value & P value \\
\cline { 1 - 1 } Serum level of 25 $(\mathrm{OH}) \mathrm{D}$ & 0,261 & 0,125 \\
\hline T-Skor & 0,25 \\
\hline
\end{tabular}

For the category of body mass index and overweight normoweight found all subjects with high levels of $\leq 20 \mathrm{pg} / \mathrm{ml}$, while the obese group were also found with the highest levels of $\leq 20 \mathrm{pg}$ / $\mathrm{ml}$ as many as five people $(55.6 \%)$.

Statistically with Chi-square test showed no significant differences in serum estradiol levels based on the characteristics of old age and menopause ( $p>0.05$ ) but there are significant differences in serum estradiol levels based on body mass index $(p=0.005)$.

Based on the Spearman correlation test between serum levels $25(\mathrm{OH}) \mathrm{D}$ with T-score, it was found that there is no significant correlation, with correlation value $r=0,261$ and $p>0,05$.

THE RESULTS OF CORRELATION TEST LEVELS OF 25 (OH) D SERUM WITH A SCORE OF BONE DENSITY.

\begin{tabular}{|l|c|c|}
\hline Research variable & R value & P value \\
\cline { 1 - 1 } Serum level of estradiol & 0,530 & 0,001 \\
\cline { 1 - 1 } T-Skor & & \\
\hline
\end{tabular}

Based on Spearman correlation test between the serum levels of estradiol with T-scores showed that there is a significant positive correlation, with the strength of the correlation $\mathrm{r}=0.53$ and $\mathrm{p}<0.05$. This shows the level of correlation between the serum levels of estradiol were with T-scores.

TABLE VII

THE RESULTS OF CORRELATION TEST LEVELS OF 25 (OH) D AND SERUM ESTRADIOL ON BONE DENSITY SCORE.

\begin{tabular}{|c|r|r|c|}
\hline Research Variable & R value & R Square & P value \\
\cline { 1 - 1 } Serum level of 25(OH)D & 0,66 & & 0,0 \\
\cline { 1 - 1 } \cline { 1 - 1 } Serum level of estradiol & 3 & 0,44 & 00 \\
\cline { 1 - 1 } T-Skor & & & \\
\hline
\end{tabular}

Based on the test results of double correlation between the levels of $25(\mathrm{OH}) \mathrm{D}$ and estradiol serum bone density score, it is known that the magnitude of the correlation levels of $25(\mathrm{OH}) \mathrm{D}$ and serum estradiol levels (simultaneously) to bone density score was calculated by the correlation coefficient is 0.663 , and $p<0.05$ it demonstrates the strength of correlation of the moderate category and thus the hypothesis that there is a significant correlation between the levels of $25(\mathrm{OH}) \mathrm{D}$ and serum estradiol with bone density of postmenopausal women received.

With the value of $\mathrm{R}$ square $=0.44$, it can be concluded that the contribution levels of $25(\mathrm{OH}) \mathrm{D}$ and serum estradiol on bone density score is $44 \%$. 
Based on Spearman correlation test between serum levels of $25(\mathrm{OH}) \mathrm{D}$ with T-scores showed that there was no significant correlation (Table 2), with the strength of the correlation $r=0.261$ and $p>$ 0.05 . Thus the hypothesis that there is a significant correlation between $25(\mathrm{OH})$ D serum level of postmenopausal women with bone density declined.

\section{IV.DISCUSSION}

Menopause is a physiological process that begins with the decline of reproductive function and hormonal changes that followed the decline of various organ function, including reduction of estrogen, the results of this study (Table 4.4) obtained serum estradiol levels $\leq 20 \mathrm{pg}$ / $\mathrm{ml}$ to $88.9 \%$ of all subjects, as well as if the review is based on the characteristics of age, duration of menopause and body mass index and overweight normoweight showed $80-100 \%$, if found 4 study subjects with higher levels can be caused by various factors such as the source of estradiol derived from ekstraglandular indicated by the index obese body mass [11], [12].

Based on this study, it was found postmenopausal women with low bone density values, only $19.4 \%$ with normal bone density, and only $4(11.1 \%)$ who have osteoporosis, seen from the fourth characteristic of this subject, entirely included in the category of obese and with higher estradiol levels, these results prove the relationship of body mass index on bone density [13], [14].

It was also found a decrease in the absorption of vitamin $\mathrm{D}$ function in the gut and decreasing levels of 7-dehydrocholesterol in the epidermis which is a provitamin $\mathrm{D}$ and therefore contributes to declining reserves of vitamin D for older women, the results of this study obtained $69.4 \%$ of menopausal women deficient in vitamin D with a cut off point of $20 \mathrm{ng} /$ $\mathrm{ml}$ (table 4.1.). Several studies determined number $30 \mathrm{ng} / \mathrm{ml}$ as the cut off point, referring to this value, the entire subject of research at the level of vitamin $\mathrm{D}$ deficiency by age category, it found levels of $25(\mathrm{OH})$ D serum of women aged $\leq 50$ years $(21.59 \pm 4.61)$ showed higher values than in older women $(15: 52 \pm 5: 33)$.

A meta-analysis has shown varying figures for the prevalence levels of $25(\mathrm{OH}) \mathrm{D}$ serum $<20 \mathrm{ng} /$ $\mathrm{mL}(50 \mathrm{nmol} / \mathrm{L})$ ranging from 1.6 to $86 \%$ of postmenopausal women who stay at nursing house [12]. international epidemiological studies recently reported approximately $64 \%$ of postmenopausal women with osteoporosis had serum $25(\mathrm{OH})$ D $<30 \mathrm{ng} / \mathrm{mL}(<75 \mathrm{nmol} / \mathrm{L})$ or $30.8 \%$ when vitamin D threshold was lowered to $20 \mathrm{ng} / \mathrm{mL}$ (50nmol / L) throughout the world. This is a large study involving 2,606 postmenopausal women with osteoporosis in 18 countries. The prevalence of deficiency $(<30 \mathrm{ng} / \mathrm{ml})$ of vitamin $\mathrm{D}$ in equatorial countries, represented by Brazil, Mexico, Malaysia, and Thailand, respectively $42.4 \%, 67.1 \%, 48.7 \%$ and $47 \%$. However, the order of prevalence would be different if the cutoff level set to $20 \mathrm{ng} / \mathrm{mL}$. Using this threshold, the countries with the highest prevalence of vitamin D insufficiency is South Korea (64.4\%), Lebanon (58.2\%), Turkey (57.9\%), Japan $(47.0 \%)$, and Germany $(33.0 \%)$. The lowest prevalence was found in Malaysia (11.3\%), Thailand (12.0\%), Sweden (12.7\%), Brazil (15.2\%), France (16.2\%), and Chile (19.1\%). ${ }^{11,13,14}$

Increasing public awareness about the negative effects of sunlight causes skin cancer has resulted in the fact that many people use sun protection and avoid sun exposure or conditions requiring to spend most of the time indoors. Lack of exposure to sunlight will cause the state of vitamin D deficiency Humans produce most of the vitamin D through exposure to the effects of UV rays on the skin. The use of a sunscreen with $\mathrm{SPF}>8$ will decrease the production of vitamin D by $95 \%$ [12].

Based on the test results of the three variables (25 $(\mathrm{OH}) \mathrm{D}$, estradiol and bone density) to a variety of risk factors, found meaningful results only on the levels of estradiol $(p=0.001)$ and bone density $(p=$ 0.016 ) on the body mass index. These results prove that the body mass index influence on the formation of estradiol from the body ekstraglandular, and the resulting increase in estradiol brought affect increases in bone mass, this is evidenced by the results of a significant positive correlation estradiol and bone density in this study.

A decrease in the activity of $25(\mathrm{OH}) \mathrm{D}$ is a marker of vitamin D status is responsible for mass bone loss [13]. Given its role in maintaining the homeostasis of calcium and phosphate, as well as the effects of secondary hyperparathyroidism caused by vitamin $\mathrm{D}$ deficiency conditions that 
would increase bone turnover, some studies try assess correlation of $25(\mathrm{OH}) \mathrm{D}$ status bone density, the research Raya PM (2001) found significant correlation between bone density levels of $25(\mathrm{OH})$ $\mathrm{D}$ serum $(\mathrm{r}=0.368$ and $\mathrm{p}=0.001)$, but in this study there was no significant correlation between them with the value of $r=0.261$ and $p<0.05$, as well as the results obtained Tangpricha V (2004) with a value of $r=0.01$ and $p=0.53$. This difference may be due to the Kingdom PM et al study, the mean old subjects of the study had experienced menopause \pm 13 years, based on the theory that there will be a decrease in bone mass by $2 \%$ since menopause occurs.

From the results of this study concluded that a significant positive correlation between serum levels of estradiol with a score of BMD, with the strength of the correlation $r=0.53$ and $p<0.05$, which means an increase in serum estradiol levels followed by elevated levels of bone density. This is in line with previous studies, some studies conducted in Indonesia is a Sulistio A (2013) research with $\mathrm{r}=0.456$ and $\mathrm{p}=0.001$ and Dewi $\mathrm{N}$ research with the value of $r=0.39$ and $p=0.001$. Based on existing theory, lack of the estrogen hormone is the etiology of primer to the occurrence of osteoporosis in postmenopausal women, in view of its function either directly or indirectly to the balance of formation and resorption of bone, with a decrease in average serum estradiol levels to the limit below 20pg / $\mathrm{ml}$ will affect the composition and bone density.

There is some increase in strength of the correlation in test double correlation between the levels of $25(\mathrm{OH}) \mathrm{D}$ and serum estradiol to score bone density with a value that is meaningful, this supports that the levels of $25(\mathrm{OH})$ D levels were positively correlated although the strength is weak and meaningless if the stand own.

\section{CONCLUSION}

The conclusion of this study is that there is no significant correlation between the levels of 25 $(\mathrm{OH}) \mathrm{D}$ serum with a T-score, with the strength of the correlation $r=0.261$ and $p>0.05$.

There is a significant positive correlation between serum levels of estradiol with a T-score, with the strength of the correlation $r=0.53$ and $p<0.05$.
There is a significant positive correlation between serum levels of $25(\mathrm{OH}) \mathrm{D}$ and estradiol together to bone density with the strength of the correlation $\mathrm{R}=$ 0.663 and $p<0.05$. Influence of serum levels of 25 $(\mathrm{OH}) \mathrm{D}$ and estradiol simultaneously on bone density score is $44 \%$.

\section{REFERENCES}

[1] Departemen Kesehatan Republik Indonesia. 2004. Available from http://www.depkes.go.id/index.php?option=news\&task=viewarticle\&si $\mathrm{d}=624 \&$ Itemid=2. On 10th March 2009.

[2] Sarmidi S, Setiyohadi B, Anggoro S. Vitamin D Status and Hyperparathyroidism in Postmenopausal Osteoporotic Patisnt in Cipto Mangunkusumo Hospital Jakarta. Indones J Intern Med. 2008.

[3] Daniele ND, Carbonelli MG, Candeloro N, Iacopino L, De Lorenzo A \& Andreoli A. Effect of supplementation of calcium and Vitamin D on bone mineral density and bone mineral content in peri- and postmenopause women A double-blind, randomized, controlled trial. Pharmacological Res 2004; 50: 637-641.

[4] Soejitno A, Kuswardhani T. Defisiensi Vitamin D: Mekanisme, Implikasi \& Terapi pada Lansia. CDK 2009; 36(2): 94-5

[5] Allali F, El Aichaoui S, Khazani H, Benyahai B, Saoub B, El Kabbaj S, et al. High prevalence of hypovitaminosis D in Morocco: relationship to lifestyle, physical performance, bone markers, and bone mineral density. Semin Arthritis Rheum. 2009 Jun;38(6):444-51

[6] F. Hosseinpanah, M. Rambod, A. Hossein-nejad, B. Larijani, F. Azizi. Association between vitamin D and bone mineral density in Iranian postmenopausal women. J Bone Miner Metab, 26 (1) (2008), pp. 8692.

[7] Rassouli A, Millanian I, Moslemi-Zadeh M. Determination of serum 25-hydroxyvitamin $\mathrm{D}(3)$ levels in early postmenopausal Iranian women: relationship with bone mineral density. Bone. 2001 Nov;29(5):428-30.

[8] NAMS Continuing Medical Education Activity. Management of Osteoporosis in Postmenopausal Women: 2010 Position Statement of The North American Menopause Society. Vol.17 No.1,pp 23-24.

[9] Clemens TL, Adams JS, Henderson SL, Holick MF. Increased skin pigment reduces the capacity of the skin to synthesize vitamin D. Lancet. 1982;1:74-6.

[10] Allali F, El Aichaoui S, Khazani H, Benyahai B, Saoub B, El Kabbaj S, et al. High prevalence of hypovitaminosis D in Morocco: relationship to lifestyle, physical performance, bone markers, and bone mineral density. Semin Arthritis Rheum. 2009 Jun;38(6):444-51

[11] Pham LT, Nguyen ND \& Nguyen TV. Quantification of the relative contribution of estrogen to bone mineral density in men and women. BMC Musculoskeletal Disorders 2013,14:366

[12] Bagur A, Oliveri B, Mautalen C, Belotti M, Mastaglia S, Yankelevich D. Low levels of endogenous estradiol protect bone mineral density in young postmenopausal women. Informa 2004;7(2):181-188

[13] Mawi M. Serum estradiol levels and bone mineral density in postmenopausal women. Univ Med 2010;29:90-5.

[14] Rogers A, Saleh G, Hannon RA, Greenfield D, Eastell A. Circulating estradiol and osteoprotegerin as determinants of bone turnover and bone density in postmenopausal women. J Clin Endocrinol Metab 2002;87:4470-5. 